\title{
Employability Requirements in the Labour Market: Analysis of Advertised Job Vacancies in Ghana
}

\author{
Sarpong Smart Asomaning ${ }^{1}$, Akom Mary Safowah ${ }^{2}$, Kusi-Owusu Emelia ${ }^{2}$, Ofosua-Adjei Irene ${ }^{2}$, Abrokwah A. \\ Moreen $^{2}$, Gyimah D. Michael ${ }^{2}$, Botwe Benjamin², Biritwum Bertrin Amponsah ${ }^{3}$ \\ ${ }^{1}$ Senior Research Fellow, Centre for Social Science Research - CSSR, Kumasi Technical University - Ghana \\ ${ }^{2}$ Team Members, CSSR, Kumasi Technical University - Ghana \\ ${ }^{3}$ Policy Analyst \& Media Practitioner. Kumasi - Ghana \\ Correspondence: Sarpong A. Smart, Senior Research Fellow, Centre for Social Science Research - CSSR, \\ Kumasi Technical University - Ghana.
}

Received: March 15, 2021

doi:10.5539/ibr.v14n5p27
Accepted: April 4, $2021 \quad$ Online Published: April 13, 2021

URL: https://doi.org/10.5539/ibr.v14n5p27

\begin{abstract}
Background: Employability is often broadly defined as an individual's ability to gain employment, to maintain employment or to replace an employment relationship by another. This study seeks to provide information on employability demands in the Ghanaian labour market.

Method: The study is based on an in-depth analysis of job advertisements in the most widely read national daily, the Daily Graphic Newspaper. Analysis of the study was done using IBM-SPSS version 25.

Results: More than half of all advertised jobs (54.3\%) were for Professionals and Management Officials. About $22.8 \%$ of all advertised jobs were open to persons with no academic qualifications. Of the remaining $77.2 \%$ that required educational qualifications, almost half $(47.3 \%)$ were open to university first degree holders. Job seekers who lack job-specific skills, computer literacy and communicative skills are not likely to succeed in the Ghanaian labour market. Also from the results, one may secure a job from age 25 and is most likely to secure a suitable job by age 35 with a minimum of 3 years of working experience. However, the likelihood of securing a job reduces as one approaches age 45 .

Conclusion: The study concludes that training and preparation for the job market should begin early enough for all prospective job seekers. Also, persons undertaking higher learning should take advantage of any small period of time in internship programs, voluntary works and industrial attachments to acquire the necessary work experiences needed to be competitive in the search for jobs in the Ghanaian labour market.
\end{abstract}

Keywords: employability, Ghana, labour market, advertisement, job vacancy, soft skills, graduate training, job seeker

\section{Introduction}

The term employability has many definitions, but is largely used to describe a person's capacity to secure and retain a job (Fugate, Kinicki, \& Ashforth, 2004; McQuaid \& Lindsay, 2005). This means that an individual may be deemed employable when he or she is able and willing to work and is successful in meeting and convincing employers that they are fit for the job, hence satisfying the vacancy conditions. York (2008) viewed employability as a set of achievements, skills, understandings and attributes which places an individual at an advantage of gaining employment and remaining relevant in his or her chosen job (Yorke, 2008). Employability skills are relevant across all industries and jobs from the labourer through to the chief executive officers (Bunt, McAndrew, \& Kuechel, 2005). To the employer however, employability will mean the possession of the required skills that will enable an employee engaged by an employer to, contribute to the institution's general goals soon after starting the job (Mason, Williams, \& Crammer, 2006). The link between a successful job search and available job vacancies is seen to be affected by knowledge about the market dynamics, effectiveness of the job search, personal qualifications and the regional distribution of labour market entry requirement and others of the like (Koen, Klehe, \& Van, 2013; McArdle, Waters, Briscoe, \& Hall, 2007; Thomsen, 2009).

In this technological age, many economies target job seekers with expectations of soft skills competencies. 
According to Winterbotham, Shury, Davies, Oldfield, Spilsbury, \& Constable (2001), most employers do not go for only academic excellence and hard skills; which are viewed as trainable on the job. Soft skills have become more and more sought after ahead of hard skills and academic excellence. Many employers therefore look out for these soft skills during job interviews and screening processes through an applicant's communication, aptitude, confidence, positive gestures, dress code, mannerisms etc (Devins \& Hogarth, 2005; Newton, Hurstfield, Miller, Page, \& Akroyd, 2005; Bunt et al., 2005; Taylor, 2005). The Learning and Skills Council of the United Kingdom reports that in 2003, over one-fifth of all advertised vacancies could not be filled owing to applicants' lack of the required soft skills. Over $70 \%$ of graduates in Malaysia do not get a job in their first 6 months after completion of school for the same lack of the required soft skills (Suresh, 2006). It has been established by many researchers that only few graduates complete university studies with sufficient soft skills and the basic appreciation of the required character to enable them to succeed in the world of work (Singh \& Singh, 2008; Kamal, 2006).

Here in Ghana, there is a profusion of evidence of high unemployment especially graduate unemployment since many jobseekers lack the prerequisite skills to acquire and to maintain their jobs. The personal awareness and competencies of the job seeker have become very much crucial in present days when the private sector is gradually taking over the provision of jobs. The importance of government as a direct provider of formal employment in Ghana has waned in the past two decades. Even more important in explaining this trend is the increasing importance of the role the private sector plays in economic activities in Ghana.

The public share of formal sector employment decreased from about $63 \%$ in 1984 to about $51 \%$ in 2000 (Twerefou, D. K., 2007) and it is still reducing. The World Bank/IMF Structural Adjustment Program (SAP) partly accounts for this trend. The 2010 population census clearly confirms the private sector as the largest employer in the country, accounting for 93.1 percent of the economically active persons (private informal, $86.1 \%$ and private formal, $7.0 \%$ ). The public sector, which is the second largest employer, accounts for only 6.3 percent (GSS Census, 2010) with Greater Accra (25.4\%), Western (14.0\%) and Ashanti (13.7\%) regions having relatively more employees in the formal sector (public or private formal) than the other seven regions (GSS Census, 2010). The growing importance of the mining, ICT and financial services sectors on one hand coupled with the decreasing involvement of government in these sectors support this assertion. The informal sector continues to provide employment for majority of the labour force. For instance, in Baah-Boateng and Turkson (2005), it is noted that in the year 2000 alone, the share of informal sector in total employment was about $80 \%$.

As such, many analysts/experts have argued that employment has become the most visible development challenge in Ghana today. Street vending and hawking has become very important in almost all urban areas of Ghana, and unfortunately, this growing trend has a "youthful face". Undoubtedly, the solution to this youth employment problem will only be effectively solved by addressing supply and demand side constraints. This Study therefore aim at providing evidence-based indicators in monitoring trends in the changing labour market in Ghana. The purpose of the study is in three folds. First, it seeks to provide information on enterprises/companies/agencies employing workers in Ghana and the types of sectors where these jobs are available. Second, we seek to provide information on educational qualifications and skills as well as the types of competencies that are demanded in the Ghanaian job market. Third, this study provides indicators for monitoring and measuring changes in the job market.

Essentially, it is expected that this study, as well as future studies on the subject, would lead to the development of a database for the continuous measurement and monitoring of advertised job vacancies in the labour market as advertised in the print media. Furthermore, it is anticipated that it would contribute to the strengthening and equipping of labour market practitioners with labour market information. This is to advance the course of efficient functioning of the Ghanaian labour market to create decent jobs, improve income and economic security for sustainable development and global competitiveness. Prospective job seekers may also find this study very helpful as it will enable them position themselves well as they adventure the labour market in Ghana.

\section{Method}

The newspaper considered as data source for this study is a public document. Many times document analysis is used in combination with qualitative research methods. However, it can be used as a standalone method (Braun and Clarke 2013) as used in this study. Key advantages of document analysis is the complete absence of obstruction in data gathering as well as the possibility of the counting of all reference range of the materials (Bowen 2009). This study benefited from the full coverage of all newspaper items published on to the Ghanaian market from January to December 2019. In this study, we took notice of the fact that not all jobs are advertised in the Ghanaian labour market. We further recognized the fact that for those jobs that are advertised there are 
various sources of advertising for job vacancies in the job market in both the electronic and print media. However, this present study is based on job advertisements in the most widely read national daily, the Daily Graphic Newspaper. This paper was chosen because of its circulation nationwide and distribution with more developed vendors widely networked. Secondly, their advertisements were also found in the other dailies. In compiling the data, extreme care is taken not to double count the adverts that appear in the subsequent editions. A questionnaire was designed to capture information such as; Job and job location, Sector declaring the vacancy, Type of skills and competencies required, Educational qualifications required, Number of previous years working experiences required, Age groups that are most sought after as well as mode of job application. Simple descriptive statistics and cross tabulations are used in presenting the findings.

\section{Results}

\subsection{Daily Distribution of 2019 Advertised Jobs}

The Daily Graphic publishes editions from Monday through to Saturday. From the daily distribution data in figure 1, Monday editions stands out as the day when most job advertisements are published. Of the three thousand four hundred and seventy-four $(3,474)$ jobs advertised over the one-year period, one thousand one hundred and one $(1,101)$ representing $31.7 \%$ of them featured in the Monday editions. The Thursday editions came next in succession in respect of days when most job advertisements were published in the Graphic. Seven hundred and eight (708) jobs, representing 20.4\% of total jobs advertised were published on Thursdays. Wednesday came third with six hundred and three (603) job advertisements representing $17.4 \%$ of total jobs advertised. Tuesdays and Fridays followed fourth and fifth positions with Five hundred and nineteen (519) and Four hundred and ninety-eight (498) jobs, representing $14.9 \%$ and $14.3 \%$ of the total advertised jobs respectively. Saturday editions of the Daily Graphic recorded a highly negligible number of job advertisements.

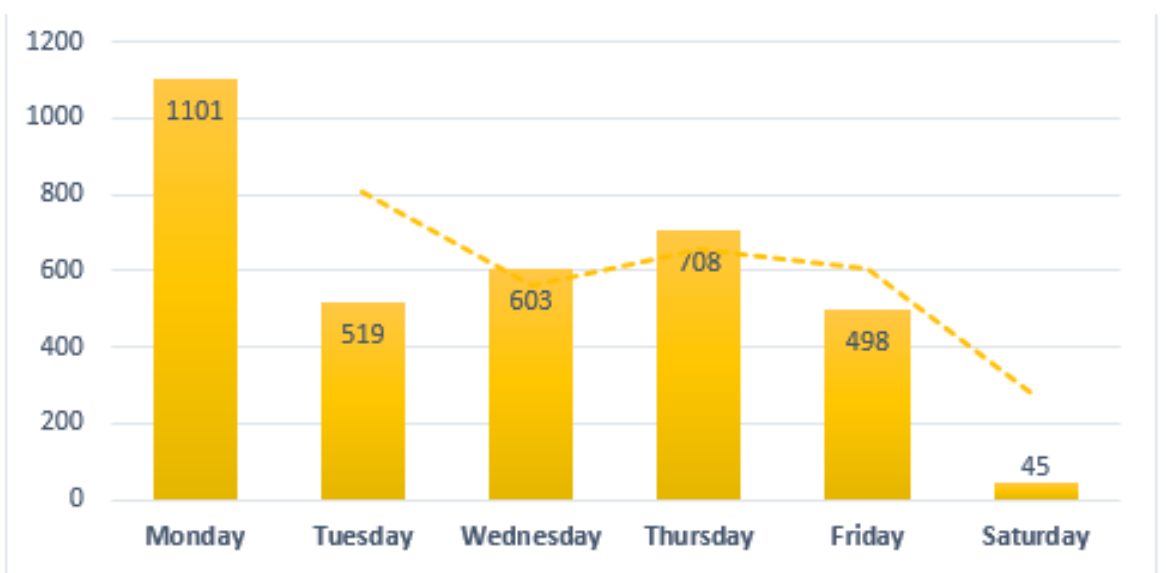

Figure 1. Distribution of 2019 Advertised jobs by days of the week

\subsection{Monthly Distribution of 2019 Advertised Jobs}

The study analyses a monthly count of advertised jobs with the aim of determining the months in which the Ghanaian labour market opens up for more jobs as compared to where the least number of jobs are opened. From figure 2, the month of May recorded the highest number of advertised jobs with five hundred and thirty-one (531) job openings, accounting for $15.3 \%$ of the total number of advertised jobs in Ghana for the year 2019. The month of February came next with four hundred and nine (409) advertised jobs representing $11.8 \%$ of total advertised jobs for 2019. The other months saw a fairly equally distributed number of advertised jobs averaging 250 jobs per month. However, the month of December recorded the least number of advertised jobs of one hundred and sixty-six (166), representing $4.8 \%$ of 2019 advertised jobs in Ghana. 


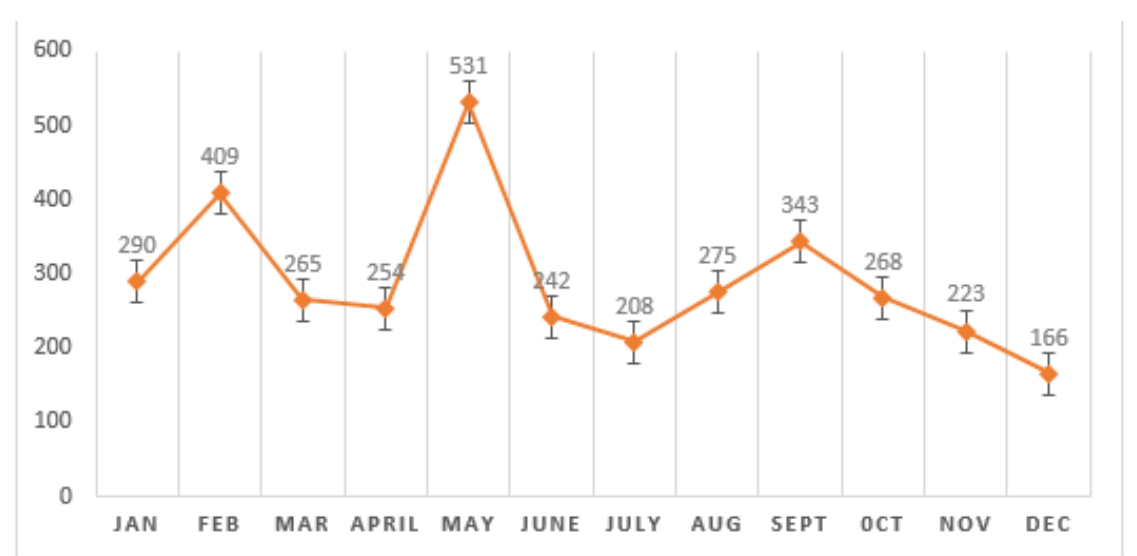

Figure 2. Distribution of 2019 Advertised jobs by Month of publication

\subsection{Distribution of 2019 Advertised Job Vacancies by Type of Ownership}

Data on the distribution of advertised vacancies by type of ownership for the period January to December 2019 is on Table 1 below. The data available in Table 3.1 indicates that out of a total of three thousand, four hundred and seventy-four $(3,474)$ jobs advertised in 2019 , a whooping Two thousand, four hundred and twenty-eight $(2,428)$ jobs representing 69.9 percent were offered by establishments that were privately owned. State owned establishments placed six hundred and forty-nine (649) advertisements representing 18.7 percent of the total job advertisements for 2019 while international organizations came as the third most opened establishment for prospective job seekers. A total of three hundred and fourteen (314) jobs representing 9.0 percent were offered by international organizations.

Table 1. Descriptive Analysis of 2019 advertised jobs

\begin{tabular}{llll}
\hline Items & & Frequency & Percent \\
& Public Sector & 649 & 18.7 \\
Type of Ownership & Private Sector & 2428 & 69.9 \\
& Joint private and public & 21 & .6 \\
& International Organization & 314 & 9.0 \\
Total & Non-Governmental Organization & 62 & 1.8 \\
\hline
\end{tabular}

Figure 3 below demonstrates that with the exception of the month of February when Public sector establishments declared more job vacancies than the private sector, all other months saw the private sector dominating the labour market with job vacancies in Ghana for the year 2019.

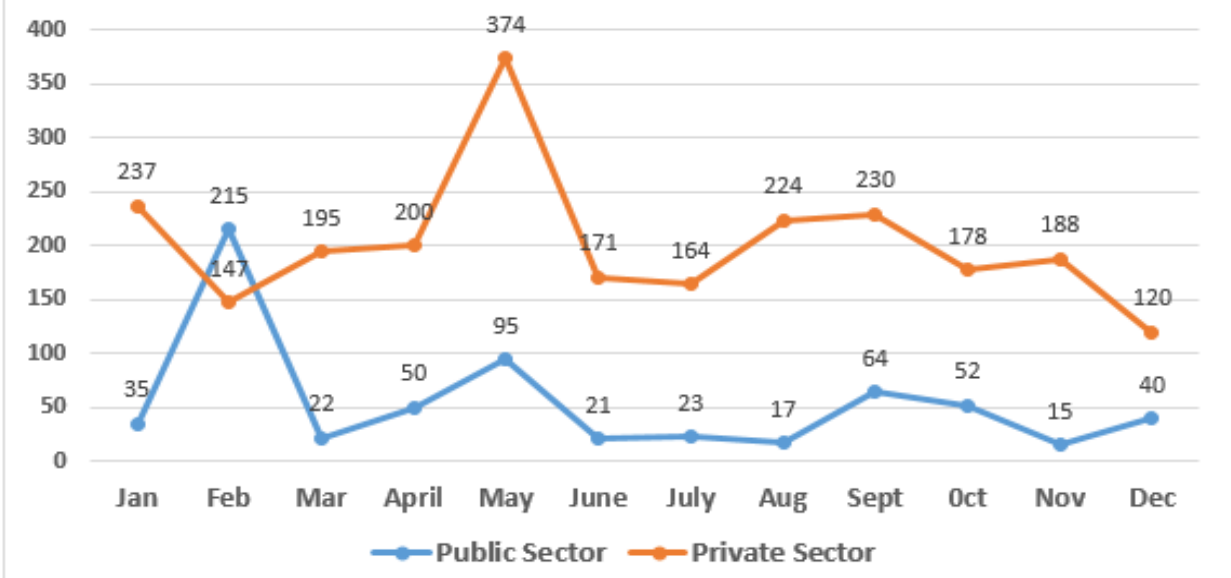

Figure 3. Comparative analysis of private and public sector advertised jobs for 2019 


\subsection{Distribution of Employment Vacancies by Occupational Group}

Table 2 presents data on the advertised vacancies by type of occupational groups.

Table 2. 2019 Advertised vacancies by Occupational groups

\begin{tabular}{|c|c|c|c|}
\hline Occupational group & & Frequency & Overall percent \\
\hline \multirow{7}{*}{ Elementary jobs } & General Labourer & 7 & \multirow{8}{*}{13.9} \\
\hline & House help & 71 & \\
\hline & Cleaners & 39 & \\
\hline & Security & 39 & \\
\hline & Hospitality & 112 & \\
\hline & Drivers & 134 & \\
\hline & Other Elementary jobs & 80 & \\
\hline Total & & 482 & \\
\hline \multirow{3}{*}{$\begin{array}{l}\text { Artisanal Jobs } \\
\text { Total }\end{array}$} & Crafts & 11 & \multirow{3}{*}{3.0} \\
\hline & Related Works & 97 & \\
\hline & & 108 & \\
\hline \multirow{2}{*}{ Clerks } & Secretary & 70 & \multirow{3}{*}{4.0} \\
\hline & Related Works & 68 & \\
\hline Total & & 138 & \\
\hline Sales \& Promotion & & 270 & 7.8 \\
\hline \multirow{5}{*}{$\begin{array}{l}\text { Administrative } \\
\text { Assistants }\end{array}$} & Accountants & 140 & \multirow{6}{*}{18.1} \\
\hline & Customer Service Co-ordination & 7 & \\
\hline & Procurement Officer & 39 & \\
\hline & Public Relation Officer & 18 & \\
\hline & Related Works & 424 & \\
\hline \multirow[t]{9}{*}{ Total } & & 628 & \\
\hline & Human Resource Managers & 36 & \multirow{19}{*}{53.2} \\
\hline & Technicians and Associate Professionals & 178 & \\
\hline & Chief Executive Officers & 31 & \\
\hline & Other Snr Management Officials & 686 & \\
\hline & Lecturers & 90 & \\
\hline & Teachers & 465 & \\
\hline & Architects & 4 & \\
\hline & Medical Officers & 80 & \\
\hline Professionals & Contractors & 30 & \\
\hline \multirow[t]{9}{*}{ Management Officials } & Lawyers & 38 & \\
\hline & Engineers & 118 & \\
\hline & Artist/Authors & 6 & \\
\hline & Designers & 8 & \\
\hline & Chemists & 5 & \\
\hline & Editors & 7 & \\
\hline & Scientist & 13 & \\
\hline & Registered Nurses & 45 & \\
\hline & Bankers & 8 & \\
\hline Total & & 1848 & \\
\hline Grand Total & & 3474 & $\mathbf{1 0 0 . 0}$ \\
\hline
\end{tabular}

It was realized that more than half of all job openings (53.2\%) was for managers, senior officials, professionals, technicians and associate professionals. An overwhelming one thousand, eight hundred and forty-eight (1848) out of the total three thousand four hundred and seventy-four (3474) advertised job vacancies were in demand of professionals and management officials. Next in demand were service workers and administrative assistants for whom a total of six hundred and twenty-eight (628) job positions were offered, representing 18.1 percent of the total jobs advertised from January to December 2019.

Interestingly but not surprising, Elementary Occupation workers came third on the league of workers in demand on the labour market with four hundred and eight-two (482) advertised jobs, representing 13.9 percent of the total jobs advertised in 2019. Drivers and hospitality workers were in high demand.

Sales and Promotion came next in demand with a total of two hundred and seventy (270) job positions representing 7.8 percent of the total jobs advertised from January to December 2019. The least sought after were Clerks (4.0\%) and artisanal workers representing 3.0 percent. Key artisanal positions opened for employment included Hairdressers, Sprayers, Upholsters, Carpenters, Mechanics, Masons, Steel Benders, Painters, Electricians, Plumbers, Tailors, Seamstress, Florists, Boiler Makers, Offshore Scaffolders, Welders, Burners, Riggers and Bakers. For the clerks and related works demand, jobs were largely opened to Receptionists, Front 
Desk Officers, Accounts Clerks, Data Entry Clerks, Office Assistants, General Clerks, Call Centre Agents, Site Clerks, Cashiers, Typists, Office Assistants, and Porters.

\subsection{Distribution of Employment Vacancies by Educational Attainment}

About seven hundred and ninety-three (793) out of the total three thousand, four hundred and seventy-four (3474) advertised jobs in 2019 did not require applicants to hold any academic qualification. Of the remaining two thousand six hundred and eighty-one (2681) that required educational qualification, almost half (47.3\%) representing 1,268 out of 2,681 of the advertised jobs were opened to university first degree holders as evident in Figure 4. Postgraduate master's holders followed closely with five hundred and forty-four (544) openings representing $20.3 \%$. Higher National Diploma (HND) and other Diplomas accounted for four hundred and ninety-two (492) openings representing $18.4 \%$. An expectedly low number of jobs (180) were opened for PhD holders, representing $6.7 \%$ of the total job vacancies advertised for 2019. The study indicates that less than 7 percent of the advertised job vacancies went to people whose educational qualifications were below the secondary level.

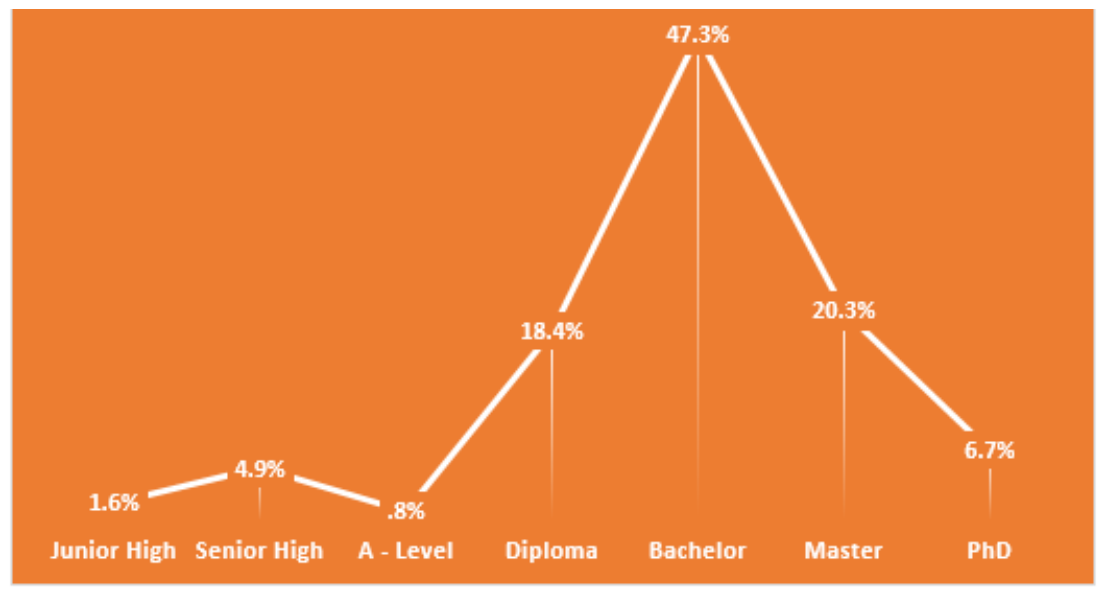

Figure 4. Vacancies by Educational Qualification

\subsection{Other Skills and Competencies Required}

Table 3. Key Competencies required on the labour market

\begin{tabular}{llll}
\hline \multirow{2}{*}{ Key Competencies } & Responses & & Percent of Cases \\
\cline { 2 - 3 } & $\mathrm{N}$ & $\mathbf{7 . 5 \%}$ & $23.4 \%$ \\
Teamwork skills & 509 & $\mathbf{2 7 . 0 \%}$ & $84.8 \%$ \\
Sector Specific skills & 1846 & $\mathbf{1 0 . 8 \%}$ & $33.9 \%$ \\
Communication & 737 & $\mathbf{1 2 . 5 \%}$ & $39.2 \%$ \\
Computer ability skills & 854 & $1.0 \%$ & $3.0 \%$ \\
Ability to adapt and act in new situations & 66 & $\mathbf{5 . 1 \%}$ & $15.9 \%$ \\
Good reading and writing skills & 346 & $\mathbf{5 . 0 \%}$ & $15.6 \%$ \\
Analytic and Problem solving skills & 340 & $\mathbf{5 . 1 \%}$ & $15.9 \%$ \\
Planning and Organization & 347 & $.9 \%$ & $2.8 \%$ \\
Decision making Skills & 61 & $.5 \%$ & $1.5 \%$ \\
Numeracy skills & 33 & $\mathbf{4 . 9 \%}$ & $15.4 \%$ \\
Leadership skills & 335 & $.6 \%$ & $2.0 \%$ \\
Operations management skills & 44 & $.9 \%$ & $2.8 \%$ \\
Marketing skills & 61 & $\mathbf{5 . 5 \%}$ & $17.3 \%$ \\
Good Human Relation & 376 & $1.0 \%$ & $3.2 \%$ \\
Working for long hours & 70 & $.8 \%$ & $2.7 \%$ \\
Work during weekends & 58 & $\mathbf{2 . 0 \%}$ & $6.4 \%$ \\
Driving skills & 139 & $\mathbf{2 . 0 \%}$ & $6.2 \%$ \\
Technical skills & 135 & $\mathbf{5 . 3 \%}$ & $16.7 \%$ \\
Management skills & 364 & $.0 \%$ & $.0 \%$ \\
Catering skills & 1 & $1.6 \%$ & $5.1 \%$ \\
Others & 110 & $\mathbf{1 0 0 . 0 \%}$ & $\mathbf{3 1 3 . 8 \%}$ \\
Total & $\mathbf{6 8 3 2}$ & & \\
\hline
\end{tabular}


The study also identified that besides the academic qualifications of job seekers, there are other skills and competencies that employers are looking for from job seekers in the Ghanaian labour market. The best four skills required by the Ghanaian labour market include sector specific skills (27.0\%), Computer literacy skills (12.7\%), Communication skills (10.8\%) and Teamwork skills (7.5\%). The next set of soft skills include Good Human Relation (5.5\%), Management skills (5.3), Good reading and writing skills (5.1\%), Planning and Organization (5.1\%), Analytic and Problem solving skills (5.0\%) and Leadership skills (4.9\%). Other skills were required in minimal proportion as evident in Table 3.3 above.

\subsection{Duration of Advertisement, Age and Working Experience Requirements}

The data available indicates that nearly $60 \%$ of jobs available require job seekers to apply within an average of fourteen days from the day of advertisement. From Table 3.4 below, both the median and the mode reveals that job advertisements last for about two weeks from the day of advertisement to the deadline. From the spread measures (the $25^{\text {th }}$ and the $75^{\text {th }}$ percentiles), adverts last between 8 days to 16 days. The data available further indicates that only about $6.4 \%$ of 2019 advertised jobs specified limits on age. The mean minimum age requirement was 30 years and the mean maximum age was 39 years, the minimum median age required was 30 years and 35 years for the maximum median age. The mode reveals 30 and 35 minimum and maximum age requirements respectively for the 2019 advertised job vacancies. From the spread measures (the $25^{\text {th }}$ and the $75^{\text {th }}$ percentiles), the least most robust age one is likely to secure a job was estimated as 25 years while the maximum

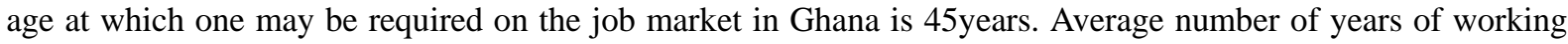
experience required was found to be 5years by the time of job vacancy while the spread ranges from 3years to 10 years (the $25^{\text {th }}$ and the $75^{\text {th }}$ percentiles).

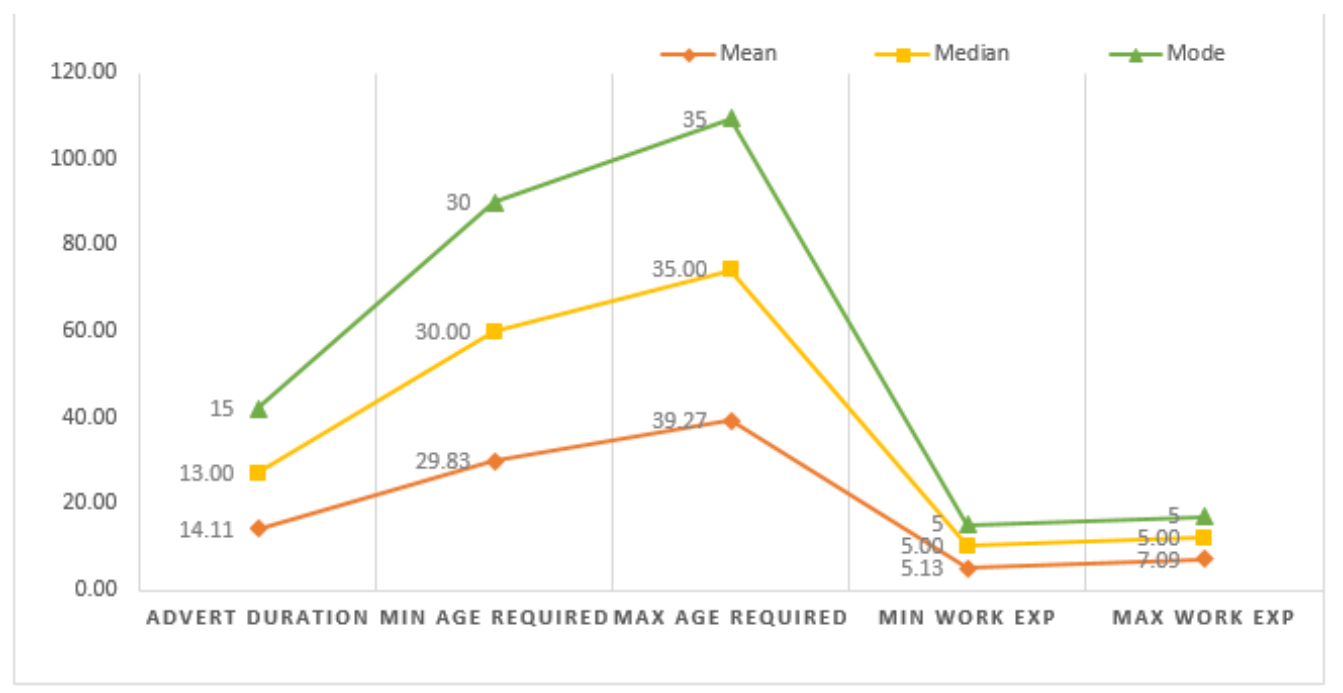

Figure 5. Averages on duration of advert, age and working experience requirements

Table 4. Basic Statistics on duration of advert, age and working experience requirements

\begin{tabular}{lllllll}
\hline & \multirow{2}{*}{ Advert Duration } & $\begin{array}{l}\text { Min Age } \\
\text { Required }\end{array}$ & $\begin{array}{l}\text { Max } \\
\text { Required }\end{array}$ & Age & Min work exp & Max work exp \\
\hline $\mathrm{N}$ & Valid & 1968 & 223 & 212 & 1639 & 211 \\
& Missing & 1506 & 3251 & 3262 & 1835 & 3263 \\
Mean & 14.11 & 29.83 & 39.27 & 5.13 & 7.09 \\
Std. Error of Mean & .177 & .518 & .769 & .075 & .255 \\
Median & 13.00 & 30.00 & 35.00 & 5.00 & 5.00 \\
Mode & 15 & 30 & 35 & 5 & 3.700 \\
Std. Deviation & 7.869 & 7.735 & 11.198 & 3.026 & .674 \\
Skewness & 1.518 & .961 & -.136 & 1.226 & -.465 \\
Kurtosis & 3.360 & 1.371 & .888 & 1.667 & 5.00 \\
Percentiles & 25 & 8.00 & 25.00 & 35.00 & 3.00 & 10.00 \\
& 75 & 16.00 & 32.00 & 45.00 & 6.00 & \\
\hline
\end{tabular}




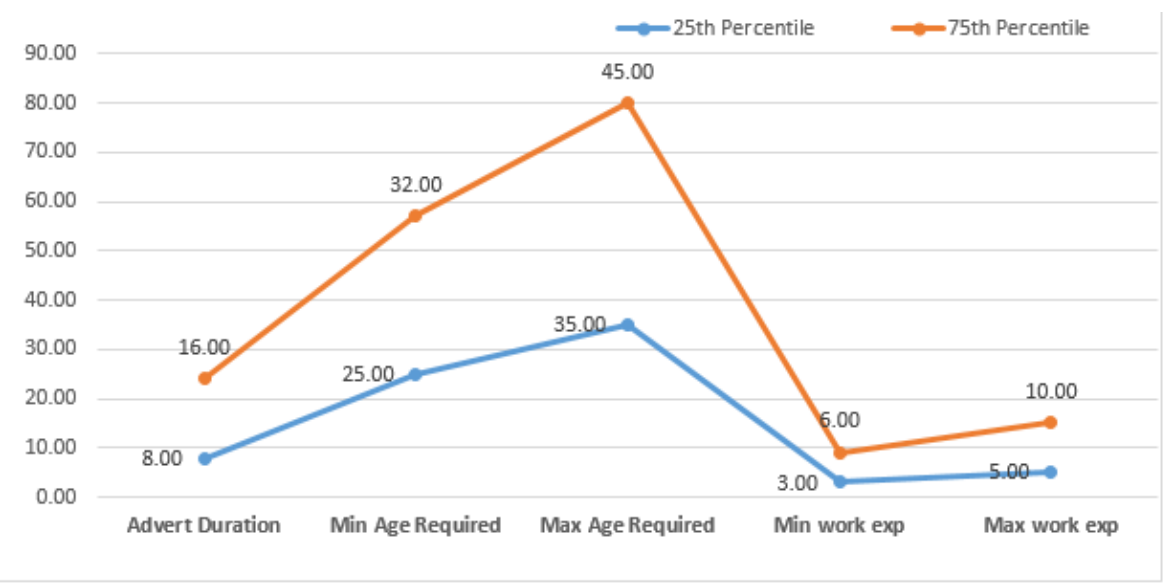

Figure 6. Percentiles of duration of advert, age and working experience requirements

\subsection{Applying for the Job}

The mode of employment application is captured in this report to draw prospective applicant's attention to the need to take such modes seriously in their training stage; CV preparation, writing a suitable application letter, and the use of email as a means of delivering your application. From Table 5 below, almost one-fourth (25.8\%) of all job openings were in demand of a Curriculum Vitae (CV). This was followed by an application letter (20.6\%) and via E-mail mode (18.5\%). All prospective job applicants are therefore advised to master these three vitals. A bad CV means irrespective of your ability or suitability; you may not pass the CV sorting stage of employee selection.

Table 5. Mode of employment application

\begin{tabular}{llll}
\hline & Responses & \\
\cline { 2 - 3 } & $\mathrm{N}$ & Percent & Percent of Cases \\
\hline CV & 2201 & $25.8 \%$ & $63.4 \%$ \\
Application letter & 1755 & $20.6 \%$ & $50.6 \%$ \\
Via contact number & 1068 & $12.5 \%$ & $30.8 \%$ \\
Certificate & 505 & $5.9 \%$ & $14.6 \%$ \\
Login portal & 190 & $2.2 \%$ & $5.5 \%$ \\
Hand delivery & 196 & $2.3 \%$ & $5.7 \%$ \\
Via E-mail & 1583 & $18.5 \%$ & $45.6 \%$ \\
Both E-mail and hand delivery & 142 & $1.7 \%$ & $4.1 \%$ \\
Postal Address & 671 & $7.9 \%$ & $19.3 \%$ \\
Media platforms & 223 & $2.6 \%$ & $6.4 \%$ \\
Total & $\mathbf{8 5 3 4}$ & $\mathbf{1 0 0 . 0 \%}$ & $\mathbf{2 4 6 . 0 \%}$ \\
\hline
\end{tabular}

In addition to all of the above discussed requirements for the Ghanaian labour market, including number of years working experience, computer literacy, valid driving license and the data available indicate further that some of the advertised job vacancies sought for job seekers who could communicate in one or more of the two most populous foreign languages, which are English and French.

Table 6. Foreign languages requirement

\begin{tabular}{lccl}
\hline \multirow{2}{*}{ items } & \multicolumn{2}{c}{ Responses } & Percent of \\
\cline { 2 - 3 } & $\mathrm{N}$ & Percent & Cases \\
\hline English & 305 & $63.5 \%$ & $80.5 \%$ \\
French & 113 & $23.5 \%$ & $29.8 \%$ \\
Arabic & 4 & $.8 \%$ & $1.1 \%$ \\
Spanish & 2 & $.4 \%$ & $.5 \%$ \\
Other international language & 9 & $1.9 \%$ & $2.4 \%$ \\
Local Languages & 47 & $9.8 \%$ & $12.4 \%$ \\
Total & 480 & $100.0 \%$ & $126.6 \%$ \\
\hline
\end{tabular}


From Table 6, out of the about four hundred and eight advertised job openings that required the ability to speak a foreign language, three hundred and five (305) representing 63.5\% sought for those who could speak or work using the English language while one hundred and thirteen (113) representing $23.5 \%$ of the job positions advertised sought for those with French speaking abilities. Very low demand was available for job seekers with Arabic and Spanish speaking abilities.

\section{Discussion}

\subsection{Employability Requirements}

What makes up an employable individual is seen by many researchers (Allen et al. 2013; Fejes 2010; Garsten and Jacobsson 2013) as one's ability to exhibit sufficient human capital relevant for a potential employer. It is clearly shown in this study that people seeking jobs are to make good use of the newspapers as they seek employment. Knowing the clear ranking of days of the week in which the majority of jobs are likely to be advertised enables a job seeker who is unable to afford all editions to target at least one day when most jobs are advertised. This study suggests Monday's edition of the Daily Graphic in the case of a job seeker in the Ghanaian labour market. Even in the event of their inability to afford the cost of buying the newspaper, they can try and visit the news stands on Mondays, Wednesdays and Thursdays and seek the consent of vendors to scan for advertised jobs. If this trend should persist, where the majority of jobs shall be available in February and May than all other months of the year (as revealed by this study), then prospective job seekers will have to position themselves adequately ahead for same.

Many studies have established evidence for age limit requirements for the prospective employer (Allen et al. 2013; Kelan 2014; Reid and LeDrew 2013). Understanding the trends in advertisement duration, age requirements and the number of years of working experience required are useful in guiding readers and prospective job seekers ahead of seeking jobs. Timing for your required job and meeting application deadlines are as key as ever. Knowledge of the advertisement lifespan may be useful in tracking jobs. Also, of outmost interest is the age limit requirement for securing jobs in the Ghanaian labour market. The age pyramid observed from the data suggests that all other things being equal, one may secure a job by age 25 . The peak age however was found to be around age 35 from whence the likelihood of obtaining a job reduces as one approaches the age 45 mark. Training and preparation for the job market should therefore begin early enough so as to be properly positioned for the rather few jobs that will be advertised.

It is also interesting to observe that prospective job applicants may be required to demonstrate a minimum of 3 years of working experience prior to securing jobs. This requirement; years of work experience has very solid confirmation in employment literature (Eggenhofer-Rehart et al. 2018; Larsen et al. 2018; Mancinelli et al. 2010; van Riemsdijk et al. 2016). This study affirms that; the chances of securing jobs were found to be directly associated with the years of relative working experience. The advice therefore is that prospective job seekers should take advantage of any small space off time to take on internship programs, voluntary works and industrial attachments to build on the necessary work experiences required in order to be competitive in the search for jobs in the Ghanaian labour market. Mandatory National Service and the Nation Builders Corps (NABCO) have provided timely avenues for our teeming unemployed graduates to secure at least the minimum required three (3) years of working experience. It therefore comes not as a surprise that even before the three-year term expires for the first batch of beneficiaries, over 20,000 of them have already secured full time jobs and have exited the programme.

\subsection{Government must Partner with the Private Sector (More Action Less Talk)}

The private sector dominating vacancies in the labour market in Ghana is in order. It is a long existing belief that the Private sector is the engine of growth. Apart from the structural ministries, departments and agencies of Government that must exist and flourish, the key target of governments should be to create the needed environment to propel the growth of the private sector. The preponderance of the private sector in the demand for jobs is a reflection of the ongoing transformation in the Ghanaian labour market with the private sector playing a leading role in job creation. Judging from the proportion of advertised vacancies by the private sector as compared to those placed by the government institutions, the private sector can be relied upon to play its role as the engine of growth in the economy. Strategic partnership must continuously be built between Government and the Private sector in the area of job creation. It is laudable that the concept of One District One Factory is pivoted on the private sector. Let more of such partnerships be seen in the mechanization of Ghana's Agricultural sector, Sanitation, Infrastructural expansion in the area of affordable housing, Tourism, Roads, Railways, Aviation and Freights. A deliberate agenda on import substitution should drive the creation of a conducive environment for the private sector such that only captains who intend to industrialise the Ghanaian labour market benefits from same. 


\subsection{Manpower Training and Development}

By far, more jobs exist for persons of the professional class than for all other groups of prospective job seekers. What this implies is that persons who may seek jobs on the Ghanaian labour market may have to carefully assess their interest areas and build a profession in such fields to enhance their chances of securing such jobs that may come their way. Other senior management officials' category, and of course the Teaching profession as well as those of the Technician class stand a greater chance of securing jobs. One key aspect of this study is its aim to add to research on labour entry requirements and the role of social categorizations such as the applicant's transferable competencies (Bernhard-Oettel and Näswall 2015), and previous education attainment (Eggenhofer-Rehart et al. 2018; Larsen et al. 2018). Let us therefore guide the training and research sections of our national life and redirect same to technical and vocational related professions; it will do us good in our quest to building an industry driven economy. The middle class jobs also featured significantly during the year under review. We must therefore devote more energies into developing such middle level manpower. It is also instructive to note that of the elementary jobs class, drivers and persons with hospitality background dominated significantly. This feeds into the need to offer access to more vocational and technical apprenticeship training to persons who are unable to further their education.

\subsection{Prioritizing Higher Learning}

Though the cost of education is quite high, prospective job seekers should try hard to advance in learning at least to the Bachelor's degree level (Eggenhofer-Rehart et al. 2018; Larsen et al. 2018). This largely enhances their chances of securing jobs on the Ghanaian labour market. In fact, over $74.4 \%$ of all jobs advertised from January to December 2019 were opened to persons with Bachelor's degree or higher. This should be a wakeup call for all citizens especially prospective job seekers. They will enhance their chances of survival in the competition for the rather scarce job vacancies by advancing in education. The pyramid as at now favours higher learning and citizens should take note. It is advised that persons undergoing academic training in bachelors or higher learning should try and be consistent with their fields of learning. Having different program degrees will largely not enhance one's chances of securing jobs in the labour market. Jack of all trades is likely to make one a master of none.

\subsection{Improving Your Soft Skills}

Deliberate attempts should be made by students and prospective job seekers to acquire and improve their soft skills and other competencies. Soft skills are actually different from hard skills and prospective job seekers should be aware and position themselves accordingly. Whereas hard skills are acquired through training in one's profession, soft skills are a combination of people-skills, social skills, communication skills, character or personality traits, attitudes, career attributes, social intelligence and emotional intelligent quotient, among others, that enable people to navigate their environment, work well with others, perform well and achieve their goals with complementing hard skills. For example, the Journalist must demonstrate absolute journalism skills at the point of seeking a job and so shall be required of the seeker of a Construction, teaching, Banking jobs and all other jobs. However, what makes you most preferred is your demonstration of soft skills such as Communication skills and Teamwork skills, Good Human Relations, Management skills, Good reading and writing skills, Planning and Organization, Analytic and Problem solving skills and Leadership skills. Many of these soft skills are not taught in class nor while in training. Even for jobs not requiring higher education, confirmation of prior skills within that vocation is a requirement (Diedrich 2017). Unfortunately, we have found similar trends regarding academic professions. Perhaps the tedious validation procedures currently in place would be redundant in a more flexible system than the present. Attending conferences, workshops, internship programs, voluntary attachments and community service are very good means of maximizing one's ability to the acquisition of such soft skills.

\section{Conclusion}

Evidence outlined in this study, supports the assertion that Ghana faces an important policy challenge in her efforts at absorbing its trained workforce in the formal sector. Developing an inclusive labour market and reducing long term unemployment, providing interventions in the labour market to create jobs for the unemployed, and providing incentives for job attachments and the job training programmes must dominate Governments efforts henceforth. The quest for professional and management Officials, academic qualification, skills requirements, age limits and number of years of working experience are all important matters for labour market analysis and for policy-making.

\section{Author Contributions:}

This manuscript is a collaborative work among the authors, spear headed by SAS the lead author. SAS 
conceptualized the entire study, designed the methods and instruments for data collection and analysis and coordinated the entire study. O-AI, AAM, GDM and BB drafted the literature on employability, collected data for the study and assisted in the final drafting. EK-O, B-NAK and MSA drafted the study background and assisted in the drafting of the report. SAS supervised the entire study process and previewed final draft manuscript.

\section{Funding: None}

Institutional Review Board Statement: Not applicable.

Informed Consent Statement: Not Applicable

Data Availability Statement: The data presented in this study are available on request from the corresponding author.

Conflicts of Interest: The authors declare no conflict of interest.

\section{References}

Allen, K., Jocey, Q., Sumi, H., \& Anthea, R. (2013). Becoming employable students and "ideal" creative workers: exclusion and inequality in higher education work placements. British Journal of Sociology of Education, 34, 431-52. https://doi.org/10.1080/01425692.2012.714249

Baah-Boateng, W., \& Turkson, E. F. (2005). Employment. In Globalisation, Employment and Poverty Reduction: A Case Study of Ghana, Aryeetey E (ed). ISSER Publication, University of Ghana: Accra; 104-139. ISBN: 9964-75-050-1.

Bernhard-Oettel, C., \& Näswall, K. (2015). Career continuance and transfer of competencies after job transitions: Insights from a Swedish study. In Handbook of Research on Sustainable Careers. Edited by Beatrice van der Heijden and Ans De Vos. Cheltenham: Edward Elgar, pp. 381-97. https://doi.org/10.4337/9781782547037.00030

Bowen, G. A. (2009). Document analysis as a qualitative research method. Qualitative Research Journal, 9 , 27-40. https://doi.org/10.3316/QRJ0902027

Braun, V., \& Clarke, V. (2013). Successful Qualitative Research: A Practical Guide for Beginners. London: Sage.

Breaugh, J. A. (1992). Recruitment: Science and practice. Boston: PWS-Kent Simon A. (2013). Definition of validation levels and other related concepts v01307. Working document. Retrieved from https://webgate.ec.europa.eu/fpfis/mwikis/essvalidserv/images/3/30/

Bunt, K., McAndrew, F., \& Kuechel, A. (2005). Jobcentre Plus Employer (Market View) Survey 2004. Sheffield: DWP.

Chertkovskaya, E., Watt, P., Tramer, S., \& Spoelstra, S. (2013). Giving notice to employability. Ephemera, 13(4), 701-716.

Citizens Advice. (2014). Topping-up and dropping-out: self-disconnection among prepayment meter users.

Devins, D., \& Hogarth, T. (2005). Employing the unemployed: Some case study evidence on the role and practice of employers. Urban studies, 42(2), 245-256. https://doi.org/10.1080/0042098042000316128

Diedrich, A. (2017). Validation of immigrants' prior foreign learning as a framing practice. European Management Journal, 35, 729-36. https://doi.org/10.1016/j.emj.2017.05.008

Eggenhofer-Rehart, P. M., Markus, L., Katharina, P., Dominik, Z., Wolfgang, M., \& Johannes, S. (2018). Refugees' career capital welcome? Afghan and Syrian refugee job seekers in Austria. Journal of Vocational Behavior, 105, 31-45. https://doi.org/10.1016/j.jvb.2018.01.004

Ekinsmyth, C. (1999). Professional workers in a risk society. Transactions of the Institute of British Geographers, 24(3), 353-366. https://doi.org/10.1111/j.0020-2754.1999.00353.x

Fejes, A. (2010). Discourses on employability: constituting the responsible citizen. Studies in Continuing Education, 32, 89-102. https://doi.org/10.1080/0158037X.2010.488353

Fugate, M., Kinicki, A. J., \& Ashforth, B. E. (2004). Employability: A psycho-social construct, its dimensions, and applications. Journal of Vocational behavior, 65(1), 14-38. https://doi.org/10.1016/j.jvb.2003.10.005

Garavan, T. N. (1999). Employability, the emerging new deal? Journal of European Industrial Training. https://doi.org/10.1108/jeit.1999.00323aaa.001 
Garsten, C., \& Kerstin, J. (2013). Sorting people in and out: The plasticity of the categories of employability, work capacity and disability as technologies of government. Ephemera: Theory and Politics in Organizations, 13, 825-50.

Ghana. Statistical Service. (2014). 2010 Population and Housing Census Report. Ghana Statistical Service.

Goldwyn-Simpkins, H., Ball, C., Montgomery, J., Grey, B., Hill, G., Howie, J., \& Palmer, K. (2015). What do graduates do. Manchester: Prospects/AGCAS.

Harper, R. (2012). The collection and analysis of job advertisements: A review of research methodology. Library and Information Research, 36(112), 29-54. https://doi.org/10.29173/lirg499

Harvey, L. (2001). Defining and measuring employability. Quality in Higher Education, 7(2), 97-109. https://doi.org/10.1080/13538320120059990

Hillage, J., \& Pollard, E. (1998) Employability: developing a framework for policy analysis (London, Department for Education and Employment).

Kamal, K. (2006). Training Approach for the Employability of Graduates: Critical Graduate Competencies in the Changing World. Paper presented at National Conference on Continuing Technical Education \& Training 2006, Challenges in Technical Education and Training: Enhancing Employability among Graduates 28-29 July 2006.

Kelan, E. K. (2014). From biological clocks to unspeakable inequalities: The intersectional positioning of young professionals. British Journal of Management, 25, 790-804. https://doi.org/10.1111/1467-8551.12062

Koen, J., Klehe, U. C., \& Van Vianen, A. E. (2013). Employability among the long-term unemployed: A futile quest or worth the effort? Journal of Vocational Behavior, 82(1), 37-48. https://doi.org/10.1016/j.jvb.2012.11.001

Larsen, E. N., Adrian, F. R., \& Gunn, E. B. (2018). Perfect for the job? Over-qualification of immigrants and their descendants in the Norwegian labour market. Social Inclusion, 6, 78-103. https://doi.org/10.17645/si.v6i3.1451

Lowden, K., Hall, S., Elliot, D., \& Lewin, J. (2011). Employers' perceptions of the employability skills of new graduates. London: Edge Foundation.

Mancinelli, S., Massimiliano, M., Piva, N., \& Ponti, G. (2010). Education, reputation or network? Evidence on migrant worker's employability. The Journal of Socio-Economics, 39, 64-71.

https://doi.org/10.1016/j.socec.2009.08.002

Mason, G., Williams, G., \& Crammer, S. (2006). Employability skills initiatives in Higher Education: What effects do they have on graduate labour market outcomes? London: National Institute of Economic and Social Research and Institute of Education.

McArdle, S., Waters, L., Briscoe, J. P., \& Hall, D. T. T. (2007). Employability during unemployment: Adaptability, career identity and human and social capital. Journal of vocational behavior, 71(2), 247-264. https://doi.org/10.1016/j.jvb.2007.06.003

McQuaid, R. W., \& Lindsay, C. (2005). The concept of employability. Urban studies, 42(2), 197-219. https://doi.org/10.1080/0042098042000316100

Messum, D., Wilkes, L., Peters, K., \& Jackson, D. (2016). Content analysis of vacancy advertisements for employability skills: Challenges and opportunities for informing curriculum development. Journal of Teaching and Learning for Graduate Employability, 7(1), 72.

https://doi.org/10.21153/jtlge2016vol7no1art582

Newton, B., Hurstfield, J., Miller, L., Page, R., \& Akroyd, K. (2005). What employers look for when recruiting the unemployed and inactive: skills, characteristics and qualifications. Research Report-Department for Work and Pensions, 295.

Oliver, B. (2015). Redefining graduate employability and work-integrated learning: Proposals for effective higher education in disrupted economies. Journal of Teaching and Learning for Graduate Employability, 6(1), 56-65. https://doi.org/10.21153/jtlge2015vol6no1 art573

Reid, C., \& LeDrew, R. A. (2013). The burden of being “employable": Underpaid and unpaid work and women's health. Journal of Women and Social Work, 28, 79-93. https://doi.org/10.1177/0886109913476944

Rothwell, A., \& Arnold, J. (2007). Self-perceived employability: Development and validation of a scale. 
Personnel review. https://doi.org/10.1108/00483480710716704

Saputra, W. S. (2015, February). Employers' needs for employability skills of engineering graduates in Indonesia. In 3rd UPI International Conference on Technical and Vocational Education and Training. Atlantis Press. https://doi.org/10.2991/ictvet-14.2015.49

Singh, G. K. G., \& Singh, S. K. G. (2008). Malaysian graduates' employability skills. Unitar e-Journal, 4(1), 14-44.

Taylor, L. A. (2005). What employers look for: the skills debate and the fit with youth perceptions. Journal of Education and Work, 18(2), 201-218. https://doi.org/10.1080/13639080500085984

Thijssen, J. G., Van der Heijden, B. I., \& Rocco, T. S. (2008). Toward the employability—link model: current employment transition to future employment perspectives. Human Resource Development Review, 7(2), 165-183. https://doi.org/10.1177/1534484308314955

Thompson, R. (2011). Individualisation and social exclusion: the case of young people not in education, employment or training. Oxford Review of Education, 37(6), 785-802. https://doi.org/10.1080/03054985.2011.636507

Twerefou, D. K. (2007): Mapping the informal economy in Ghana today: Size, structure, composition and contribution to socio-economic development, paper presented at the ISSER/Merchant Bank Development Seminar Series, Accra, January 2007.

UKCES. (2009). The employability challenge. London: UK Commission for Employability and Skills.

van Riemsdijk, M., Scott, B., \& Alana, B. (2016). Socio-cultural incorporation of skilled migrants at work: Employer and migrant perspectives. International Migration, 54, 20-34. https://doi.org/10.1111/imig.12221

Watkins, J., Drury, L., \& Preddy, D. (1992). From evolution to revolution, the pressures on professional life in the 1990s. Bristol: University of Bristol/Clerical Medical Investment Group.

Winterbotham, M., Shury, J., Davies, B., Oldfield, K., Spilsbury, M., \& Constable, S. (2010). National Employer Skills Survey for England 2009: Main report: Evidence Report 23. IFF Research and UK Commission for Employment and Skills.

Wright, J., Brinkley, I., \& Clayton, N. S. (2010). Employability and Skills in the UK: Redefining the Debate. London: The Work Foundation.

Yorke, M. (2008). Employability in higher education: What it is and what it is not. Higher Education Academy: ESECT.

Yüce, P., \& Highhouse, S. (1998). Effects of attribute set size and pay ambiguity on reactions to "Help wanted" advertisements. Journal of Organizational Behavior, 19(4), 337-352.

https://doi.org/10.1002/(SICI)1099-1379(199807)19:4<337::AID-JOB848>3.0.CO;2-V

\section{Copyrights}

Copyright for this article is retained by the author(s), with first publication rights granted to the journal.

This is an open-access article distributed under the terms and conditions of the Creative Commons Attribution license (http://creativecommons.org/licenses/by/4.0/). 